\author{
Anna Ostrowska \\ Maria Curie-Skłodowska University in Lublin, Poland \\ ORCID: 0000-0003-0058-5814 \\ ostrowska@poczta.umcs.lublin.pl
}

\title{
Effectiveness of Administrative and Legal Instruments for Animal Protection Used by Social Organizations
}

\author{
Skuteczność administracyjnoprawnych instrumentów ochrony \\ zwierząt stosowanych przez organizacje społeczne
}

\begin{abstract}
The article is devoted to the issue of the effectiveness of administrative and legal instruments of animal protection granted to social organizations under the Animal Protection Act. The research purpose of the paper is to analyze the administrative and legal conditions of the interaction of social organizations with public administration and other entities in the field of animal protection and animal care, and as a result to verify the thesis that the activity of organizations has little influence on the effectiveness of the animal protection system. In order to achieve this goal, three research theses were formulated: 1) there are no rational grounds for depriving social organizations of the competence to temporarily remove an animal, which is the most effective means of protecting mistreated animals; 2) public administration bodies and their subordinate services should make wider use of the potential of social organizations in the sphere of consultative and educational activities; 3 ) the effectiveness of the activities of social organizations in the sphere of animal protection is adversely affected by superficial regulations concerning the cooperation of organizations with administrative bodies and public services. The article is a research paper of a national range of research. The author's intention is to contribute to a broader discussion on the directions of socialization of the animal protection system.
\end{abstract}

Keywords: social organization; animal protection; animal care; temporary removal of an animal; consultative and educational activities; cooperation

CORRESPONDENCE ADDRESS: Anna Ostrowska, PhD, Assistant Professor, Maria Curie-Skłodowska University (Lublin), Faculty of Law and Administration, Institute of Law, Plac Marii Curie-Skłodowskiej 5, 20-031 Lublin, Poland. 


\section{INTRODUCTION}

The municipality is the key link in the animal protection system in Poland. This smallest and at the same time the basic unit of the local government bears the main burden of performing tasks constituting the implementation of the provisions of the Act of 21 August 1997 on the protection of animals. ${ }^{1}$ Currently, social expectations towards municipalities in this respect are higher than ever before. Animals are treated as entities experiencing physical and mental suffering. The public debate on the situation of animals therefore emphasizes the need to move away from the so-called species chauvinism, striving to blur the differences in human attitudes towards domestic and farm animals. The declared aim of the legislator, administrative bodies and courts is the care and protection of animals, not the protection of humans against animals. However, this idealistic approach does not withstand confrontation with reality. Animal shelters that do not meet basic sanitary standards, cases of temporary removal of mistreated animals, or poor living conditions of farm animals, especially on large industrial animal farms, which are theoretically under the control of veterinary services, expose the ineffectiveness of the actions of both public authorities and entities which are obliged by law to cooperate with these authorities in the sphere of animal protection. One of these entities are social organizations whose statutory purpose is animal protection.

Among the administrative instruments for animal protection at the disposal of social organizations, the so-called "hard competences" stand out. This term is used as a collective term for all legal regulations that impose strictly defined animal protection tasks on these organizations, together with an indication of the legal forms in which these tasks are to be carried out. These competences are generally exercised in the form of material and technical activities in cases of animal abuse, as well as in relation to animals deprived of care. The catalog of these competences includes: 1) informing the mayor of a case of animal abuse; 2 ) temporarily taking the abused animal away from its owner or guardian; 3) running animal shelters; 4) declaring the necessity of immediately killing an animal to end its suffering. Organizations are also given a consultative role in the process of enacting local laws on animal protection or protection against animals posing an extraordinary threat. In addition, the Animal Protection Act contains norms of a high degree of generality, expressing unspecified authorization for cooperation of social organizations with public authorities, public services and other entities in the sphere of animal protection.

This article is an attempt to evaluate the effectiveness of these legal instruments, undertaken using the dogmatic method, consisting in the analysis and interpretation of the provisions of the Animal Protection Act, taking into account the views expressed in the literature on the subject and in court rulings, as well as the positions

1 Journal of Laws 2020, item 638, as amended, hereinafter: APA. 
of representatives of social organizations. As part of this assessment, the veracity of the following theses was verified: 1) there are no rational grounds for depriving social organizations of the competence to temporarily remove an animal, which is the most effective means of protecting mistreated animals; 2) public administration bodies and their subordinate services should make wider use of the potential of social organizations in the sphere of consultative and educational activities; 3 ) the effectiveness of the activities of social organizations in the sphere of animal protection is adversely affected by the facade regulations on the cooperation of organizations with administration bodies, public services and other entities.

\section{ATTEMPT TO ASSESS THE EFFECTIVENESS OF THE "HARD COMPETENCES" OF AN ADMINISTRATIVE NATURE}

One of the key instruments granted to social organizations for the prevention of animal abuse is the authorization for the representative of the organization to inform the head of the municipality (mayor) of the cases of ill-treatment of animals as listed in Article 6 (2) APA, which generates an obligation for the authority to initiate proceedings for the temporary removal of the animal from its former owner or keeper (Article 7 (1a) APA). Furthermore, in urgent cases where the continuation of the animal with its current owner or keeper poses a threat to its life or health, a representative of a social organization shall collect the animal and immediately notify the municipality executive authority in order to take a decision on the removal of the animal (Article 7 (3) APA). A public opinion poll carried out in 2019 showed that in 2016-2018, the activity of social organizations as initiators of administrative proceedings in cases of temporary removal of animals was several times higher than the activity of the State Veterinary Inspection or Municipal Guard (e.g., in 2018, organizations initiated $58.3 \%$ of proceedings, while the State Veterinary Inspection initiated $11.1 \%$ of proceedings, and the Municipal Guard initiated $5.6 \%$ of proceedings). ${ }^{2}$ This entitles to formulate a thesis about the fundamental role of social organizations in the sphere of protection of animals from suffering inflicted on them by their owners or guardians. However, there is no shortage of opinions that in the state of law, where property is constitutionally protected, an animal (which is not a thing, but an object of property law) cannot be taken away from its owner by a private person, who is after all a representative of a social

${ }^{2}$ Fundacja Czarna Owca Pana Kota, Filantropi czy złodzieje? O czasowym odbieraniu zwierząt. Raport z monitoringu, Kraków-Wrocław 2019, https://czarnaowca.org/wp-content/uploads/ Czarna-Owca-Filantropi-Czy-Zlodzieje.pdf [access: 9.02.2021]. The monitoring included 826 randomly selected local self-government units that adjudicated cases of temporary removal of animals in 2016-2018. 
organization. ${ }^{3}$ Regardless of the dilemma concerning the constitutionality of the discussed solution, it undoubtedly exposes the incompetence of public authorities and services subordinate to them, whose duty it is to carry out animal protection tasks in forms appropriate for administrative law.

Despite the significant practical importance of the institution of temporary removal of an animal by a social organization, for the past decade judicial decisions have failed to resolve the dispute on such a fundamental issue as the legitimacy of the social organization whose representative collected the animal to act as a party in proceedings initiated by a mayor pursuant to Article 7 (3) APA. ${ }^{4}$ The fact that this issue was resolved by the Supreme Administrative Court is to be welcomed. In the resolution of 24 February $2020,{ }^{5}$ the Supreme Administrative Court held that in proceedings aimed at issuing a decision under Article 7 (3) APA, a social organization whose statutory objective is to protect animals, whose representative removed the animal and notified the mayor about it, has party status within the meaning of Article 28 of the Code of Administrative Procedure. ${ }^{6}$ There can be no doubt as to the rationality of the extensive argumentation of the Court, which basically boils down to three basic conclusions. Firstly, in the case governed by Article 7 (3) APA, as opposed to the situation under Article 7 (1) APA, ${ }^{7}$ an act of removal of the animal by a representative of the organization had already been performed.

3 This position is consistently presented by M. Rudy. See, i.a., M. Rudy, Z kolejna nowelizacja prawa ochrony zwierząt mam same problemy, „Rzeczpospolita”, 26.01.2020, www.rp.pl/Opinie/ 301269987-Michal-Rudy-Z-kolejna-nowelizacja-prawa-ochrony-zwierzat-mam-same-problemy. html [access: 17.02.2021].

${ }_{4}^{4}$ Judgement of the Supreme Administrative Court of 11 July 2018, II OSK 1002/18; judgement of the Supreme Administrative Court of 11 January 2018, II OSK 770/16; judgement of the Voivodeship Administrative Court in Wrocław of 3 January 2018, II SA/Wr 711/17; judgement of the Voivodeship Administrative Court in Lublin of 20 June 2018, II SA/Lu 218/18; judgement of the Voivodeship Administrative Court in Kraków of 22 December 2014, II SA/Kr 1495/14; judgement of the Voivodeship Administrative Court in Szczecin of 6 November 2013, II SA/Sz 965/13. Cf. judgement of the Supreme Administrative Court of 30 October 2018, II OSK 2684/16; judgement of the Voivodeship Administrative Court in Kielce of 15 March 2018, II SA/Ke 39/18. This problem has been thoroughly analyzed by P. Ostojski (Organizacja społeczna jako strona postępowania w sprawie odebrania zwierzęcia na podstawie Artykutu 7 ust. 3 ustawy o ochronie zwierząt, "Przegląd Prawa i Administracji” 2019, vol. 116, pp. 73-85). See also J. Stelmasiak, Administracyjnoprawne aspekty ochrony zwierzat, [in:] Prawna ochrona zwierząt, ed. M. Mozgawa, Lublin 2002, p. 155 ff.; P. Janiak, Czasowe odebranie zwierzęcia w trybie administracyjnym - podstawowe zagadnienia, "Casus" 2019, no. 1, p. $47 \mathrm{ff}$.

5 II OPS 2/19, CBOSA.

${ }^{6}$ Act of 14 June 1960 - Code of Administrative Procedure (Journal of Laws 2020, item 256, as amended), hereinafter: CAP.

${ }^{7}$ In a situation where a representative of a social organization merely informs the head of the municipality, pursuant to Article 7 (1a) APA, of a case of mistreatment of an animal, the organization has no legal interest of its own in the proceedings, which has not been disputed in the case law and doctrine. It may join the proceedings in accordance with Article $31 \mathrm{CAP}$. 
The decision issued under Article 7 (3) APA is therefore a subsequent settlement resulting from an assessment as to whether the statutory prerequisites for such an action had occurred at the moment of removing the animal from its owner. During the investigation procedure, the parties may present arguments and support evidence to prove the existence or non-existence of these grounds. The owner or keeper of the animal has the right to prove that the grounds for taking away the animal did not exist, while the social organization whose representative performed the action should have the right to prove that a threat to life or health of the animal existed at the time of taking away the animal. The participation of a social organization as a party will ensure an equal position of this organization in relation to the owner or keeper of the animal. If the mayor did not find the grounds for removing the animal, the organization notifying him that the animal had been removed, must have the opportunity to contest the position of the mayor, defending itself against the charge of illegal action by way of an appeal to a higher instance authority and then a complaint to the Voivodeship Administrative Court. ${ }^{8}$ Secondly, the social organization could bear the costs related to the action of removing the animal, i.e. the costs of transport, maintenance and treatment. The refusal of the mayor to sanction this action by way of a decision to collect the animal excludes the possibility of the organization recovering the incurred expenses, which may result in severe financial consequences. ${ }^{9}$ Thirdly, if it is found that the removal of the animal was unjustified, the owner or keeper of the animal has a civil claim against the social organization for compensation for personal injury or non-material damage. In light of the above, there can be no doubt that a social organization has its own legal interest in proceedings under Article 7 (3) APA. The solution to the problem in question significantly strengthens the legal status of social organizations. Joining the proceedings on the rights of a party under Article $31 \mathrm{CAP}$, an organization would not have such a strong position as a party to the proceedings. It would not be able to have access to the proceedings themselves, nor to the rights or obligations which the proceedings concern, nor would it be an addressee of the decision settling the case. The new direction of case law established by the Supreme Administrative Court resolution may provide an additional impetus for representatives of social organizations to intervene under Article 7 (3) APA and, consequently, make the animal abuse prevention system more effective. It should be emphasized, however, that it met with criticism from recognized representatives of the doctrine of administrative law, who stated that the Supreme Administrative Court erroneously

${ }^{8}$ K. Kuszlewicz, Prawa zwierząt. Praktyczny przewodnik, Warszawa 2019, pp. 222-223.

9 W. Radecki, Ustawa o ochronie zwierzat. Komentarz, Warszawa 2015, p. 85; judgement of the Supreme Administrative Court of 30 October 2018, II OSK 2684/16; judgement of the Supreme Administrative Court of 3 July 2019, II OSK 1162/18. 
decoded the normative meaning of the phrase "collects the animal" used in Article 7 (3) APA, which determined the further course of its reasoning. ${ }^{10}$

Furthermore, social organizations have been authorized to run shelters for homeless animals in consultation with competent local government authorities (Article 11 (4) APA). Currently, such a shelter may be established and operated by any social organization whose statutory objective is animal protection. ${ }^{11}$ Repeated cases of ill-treatment of animals in shelters combined with an ineffective system of control over shelters give rise to reflection on the need to raise standards concerning founders of shelters. In the case of social organizations, it could consist in limiting the circle of organizations which establish and run shelters to public benefit organizations within the meaning of the Act of 24 April 2003 on public benefit activity and volunteerism. ${ }^{12}$ Statutory requirements for substantive and financial transparency of public benefit organizations' activities, as well as fiscal and tax privileges that organizations have received, would provide a stronger guarantee of proper performance of shelter tasks.

There is a well-founded controversy over the authority given to representatives (inspectors) of social organizations to determine the need to kill an animal in order to end its suffering (Article 33 (3) APA). Such a person is not required to have any professional qualifications in veterinary medicine, so there is a risk of hasty decisions to kill an animal being made by an operator who, for lack of relevant knowledge and experience, is unable to use any other method of ending the animal's suffering than killing it. The argument for taking this power away from community organizations is sound, but stronger considerations militate against this concept. ${ }^{13}$ One should bear in mind that the authorization provided for in Article 33 (3) APA is based on the assumption of acting under conditions of force majeure. As

${ }^{10}$ E. Szewczyk, M. Szewczyk, Status organizacji społecznej w postępowaniu prowadzacym do wydania decyzji na podstawie art. 7 ust. 3 in fine ustawy z dnia 21 sierpnia 1997 r. o ochronie zwierząt. Glosa do uchwaty Naczelnego Sadu Administracyjnego z dnia 24 lutego 2020 r., II OPS 2/19, "Orzecznictwo Sądów Polskich" 2020, no. 9, p. 143. The commentators stated that a representative of a social organization, acting on the basis of Article 7 (3) APA, performs an authorising act (of a police nature) and thus acts in a given case as an administrative entity. The court-administrative judicature and the legal doctrine have consistently held that in the same case, an entity cannot play two roles - as the body conducting the proceedings (the administering body) and as the party (the administered party). As a rule, these roles cannot be combined. It is also inadmissible for the same entity to occupy the position of both the authority and the party, depending on the stage of settlement of the public administration case.

${ }^{11}$ See E. Kruk, Polish and Estonian Regulations on Homeless (Stray) Animals, "Studia Iuridica Lublinensia" 2021, vol. 30(1), pp. 152-156.

12 Journal of Laws 2020, item 1057.

13 See Opinia Krajowej Izby Lekarsko-Weterynaryjnej dotyczaca poselskiego projektu ustawy o zmianie ustawy o ochronie zwierząt oraz ustawy o utrzymaniu czystości i porządku w gminach (druk $n r$ 4257), Warszawa 2011, http://orka.sejm.gov.pl/Druki6ka.nsf/0/F005D64B6021E765C12578BE0 02965C6/\$file/4257-001.pdf [access: 9.02.2021]. 
E. Kruk rightly pointed out, "in the current state of the law, an unjustified refusal by an authorized person to kill an animal to end its suffering may be regarded as unlawful, although such behavior is not sanctioned" ${ }^{14}$ The author referred to the opinion of the Legal Department of the Ministry of Environment, according to which "such a procedure when a veterinarian's opinion cannot be obtained and the extent of the injury does not raise doubts as to the actual necessity of killing the animal, is [...] incompatible with the general provisions of the Animal Protection Act. The legislator unambiguously indicated in Article 4 (3) APA that killing an animal, which can continue to live only by suffering and enduring pain, is a moral obligation of a human being. Furthermore, humane treatment of an animal, in light of the definition of this concept contained in Article 4 (2) APA, may be understood as the obligation to ensure protection against unnecessary suffering. Therefore, there is no doubt that no authorized person should refuse to kill an animal if the conditions set out in the APA are met". ${ }^{15}$

\section{AN ATTEMPT TO ASSESS THE EFFECTIVENESS OF CONSULTATIVE AND EDUCATIONAL COMPETENCES}

The municipality responsibilities concerning care for homeless animals are executed on the basis of the program of care for homeless animals and prevention of animal homelessness, which is a planning act passed obligatorily every year by the council of every Polish municipality. The purpose of the program is to gradually reduce the population of homeless animals and improve their living conditions. The socialization of the procedure of passing this act, which is now a standard in the process of planning acts, in the case of the program is realized by a statutory requirement to obtain an opinion on the draft program by social organizations whose statutory purpose is animal protection and which operate in the area of the municipality (Article 11a (7) (2) APA). ${ }^{16}$ An opinion, as opposed

${ }^{14}$ E. Kruk, Opinia nt. uwarunkowań prawnych działań organizacji społecznych na rzecz ochrony zwierzat $z$ dnia 22 stycznia $2021 \mathrm{r}$. (unpublished, prepared as part of the implementation of the research project entitled "The Administrative Law Model of Animal Protection" funded by the National Science Center, UMO-2016/23/D/HS5/01820), p. 4.

15 Opinia Departamentu Prawnego Ministerstwa Ochrony Środowiska z 26 marca 2013 r. w sprawie postępowania ze zwierzętami łownymi w szczególnych przypadkach (DP-024-10/6037/12AVB), http://bip.jaktorow.pl/upload/dp-024-10_6037_12avb_opinia_dep_prawnego_-_zwierzyna-1.pdf [access: 20.02.2021].

${ }^{16}$ An opinion of a social organization, the statutory purpose of which is to protect animals, also requires a draft resolution of the provincial assembly on the determination of the place, conditions, time and manner of limiting the population of animals posing an extraordinary threat to human life, health or economy, including hunting (Article 33a (2) APA). 
to an agreement, is not binding upon the body which has requested the opinion. ${ }^{17}$ While it is obligatory for the mayor to obtain the organization's opinion on the draft program, ${ }^{18}$ there is no obligation to take account of the organization's statement on the content of the program even if it is negative towards the proposed solutions. The form of the organization's participation in the issuance of a municipal legal act consisting in the expression of an opinion on the draft act does not guarantee the organization a real impact on its content. However, I do not consider this solution defective because since it is the municipal council that is responsible for adopting the program and the municipality is charged with implementing and financing the solutions adopted in the program, the municipal council should ultimately decide about its content. A social organization has no right to file a complaint against the program resolution to the Voivodeship Administrative Court even if the municipal council passes the program without seeking an opinion from an organization or if it adopts certain solutions against an opinion from an organization. The organization may, however, signal these issues to the provincial governor or the public prosecutor, who are entitled to file a complaint against the resolution without having to meet the prerequisite of Article 101 (1) of the Act of 8 March 1990 on municipal self-government. ${ }^{19}$

Social organizations, apart from establishing and running shelters for homeless animals, may play an important consultative and educational role in this matter. Undoubtedly, the establishment of shelters is the best known solution providing care for homeless animals, but their location is a challenge for municipal authorities as it generates social conflicts. The operation of an animal shelter is commonly associated with atmospheric pollution, possible contamination of water and soil, source of noise and odor, and source of human exposure to zoonotic diseases and animal attacks. For this reason, inhabitants of municipalities express strong resistance to plans to locate animal shelters near their places of residence. At the same time, the same inhabitants demand from the municipal authorities to create an effective system of care for homeless animals that would provide animals with decent living conditions and protect people against attacks and spreading of zoonotic diseases. The solution to this problem is not, despite appearances, locating shelters far away from residential areas, where inconveniences related to shelter operation would be unnoticeable for residents. The problem is more complex because while locating

${ }^{17}$ More on this subject K. Wlaźlak, Funkcja planowania gminy na przykładzie programu opieki nad zwierzętami bezdomnymi oraz zapobiegania bezdomności zwierząt, "Przegląd Prawa Publicznego" 2015, no. 4, pp. 41-4.

${ }_{18}$ Failure by the municipal body to consult the draft program should be considered a material breach of the program establishing procedure, resulting in its invalidity under the supervisory or administrative court procedure (Article 91 (1) of the Act of 8 March 1990 on municipal self-government, Journal of Laws 2020, item 713, as amended).

${ }^{19}$ Cf. judgement of the Supreme Administrative Court of 18 July 2015, II OSK 2776/13. 
a shelter one has to ensure convenient and easy access to it for volunteers and people willing to adopt animals. This problem cannot be solved by locating a shelter on a remote, inaccessible wasteland. ${ }^{20}$ In these circumstances, social organizations can play an important consultative and advisory role, taking part in the procedures of determining optimal locations for animal shelters by municipal authorities. By actively participating in the process of enacting local spatial planning acts which provide for the location of animal shelters, including mandatory public discussions as part of that process, they can contribute to building a forum for understanding between municipal authorities and residents and thus create an opportunity to reduce the scale of spatial conflicts.

In the area of educational activities, the knowledge and experience of representatives of social organizations can be used in the framework of training conducted by them for services, including the Police and municipal guard, which are authorized to take specific actions to protect animals, including temporary removal of mistreated animals or prosecution of offenders against animals.

Consumer education promoting positive attitudes towards animals, including the abandonment of caged hen farming, the ban on breeding animals for fur, and the ban on testing cosmetics on animals, is also effective. Making people aware of the living conditions of these animals may in the long run contribute to the cessation of this kind of activity not because it will be banned by the legislator (which will always meet with strong opposition from food, fur or cosmetics producers), but because, due to the lack of demand for these products, it will simply become unprofitable.

\section{THE PROBLEM OF THE EFFECTIVENESS OF NORMS AUTHORIZING SOCIAL ORGANIZATIONS TO COOPERATE WITH OTHER ENTITIES IN THE ANIMAL PROTECTION SYSTEM}

The Animal Protection Act authorizes social organizations to cooperate with the Veterinary Inspection in the supervision of compliance with animal protection regulations (Article 34a (3) APA), as well as with relevant state and local government institutions in the detection and prosecution of crimes and offenses set forth in this Act (Article 40 APA). The legislature stopped at this authorization, without specifying the forms of its implementation. Granting organizations the right to cooperate in exercising supervision is therefore perceived as purely illusory. ${ }^{21}$ The

20 A. Ostrowska, Location of Animal Shelters in the Local Spatial Development Plan in Poland, [in:] Legal Protection of Animals, eds. E. Kruk, G. Lubeńczuk, H. Spasowska-Czarny, Lublin 2020, pp. 249-261.

${ }^{21}$ According to Ł. Smaga (Ochrona humanitarna zwierząt, Białystok 2010, p. 270), legal regulations on the activities of social organizations in the sphere of animal protection are characterized 
discussed provision on the cooperation of social organizations with other entities in the animal protection system seems to be a facade regulation, which is an ornament rather than an effective legal instrument for animal protection.

Such legal constructs, however, are not alien to law, including administrative law. When deciding to establish them, the legislator may be guided by the conviction that in the given social system such a norm will be implemented. The legislator may also assume that in certain areas of social life flexibility in decision-making is necessary, and excessive formalism is a barrier to the efficient and creative performance of tasks. ${ }^{22}$ The addressee of the framework norm independently chooses such ways of task realization that will realize the disposition of this norm to the highest degree. "The legislator - as it seems - intends through such a legislative procedure to orient the addressees of norms to the result, to the solution of problems, and not to search for and cite provisions that are supposed, as it were, to justify their behaviour. The legislator gives the addressee a compass, so to speak, and not a map of the area with a marked route". ${ }^{23}$ These norms do not directly determine the behaviour of their addressees, hence it is difficult to assess their behaviour as fulfilling or not fulfilling their dispositions. As a consequence of the above, the norms may be executed fully, or may not be executed at all.

By authorizing various administrative entities, including social organizations, to cooperate in the sphere of animal protection, the legislator left them the choice of how to implement this authorization. Perhaps the legislator was overly optimistic in his motivations, not paying enough attention to the fact that the effectiveness of the framework regulation depends on such factors as the acceptance of the norm by its addressees, as well as certain habits and attitudes. ${ }^{24}$ It is currently difficult to speak of developed habits and attitudes favourable to cooperation in the sphere of animal protection in a situation of mutual antagonism between public authorities, veterinary services and non-governmental organizations.

It should be borne in mind first of all that the problem of effectiveness of supervision is not limited in this case to the illusory role of social organizations, but covers a broader systemic context. The basic task of the Veterinary Inspection is not the humane protection of animals dictated by ethical considerations, but the protection of human health through the protection of animal health. Only the Veterinary Inspection is indeed authorized to control the observance of regulations

by a far-reaching randomness, and the designation of specific competences of these organizations by the legislator took place without a specific concept, only to maintain the appearance of social control.

${ }^{22}$ See T. Biernat, On the Lawmaking Policy, Discretion and Importance of the Rule of Law Standards, "Studia Iuridica Lublinensia" 2020, vol. 29(3), pp. 67-85.

${ }_{23}$ J. Jabłońska-Bonca, Przesłanki stanowienia norm bez sankcji, "Ruch Prawniczy, Ekonomiczny i Socjologiczny" 1984, vol. 46(4), p. 161.

${ }^{24}$ See W. Dziedziak, Wpływ sankcji prawnych i moralnych na skuteczność prawa, "Studia Iuridica Lublinensia" 2015, vol. 24(1), pp. 67-88. 
on animal protection, but the legislator has not even equipped it with the proper authoritative instruments that would allow it to effectively exercise its competences in this scope. ${ }^{25}$

\section{CONCLUSION}

Undoubtedly, the activity of social organizations, whose statutory goal is animal protection, has a positive impact on the formation of moral attitudes towards animals and on people's sense of responsibility for their fate. However, the potential of the organizations is not fully used neither by the administration obliged to protect animals nor by the public services. Representatives of the organizations point out to the insignificant interest in cooperation on the part of municipalities, excessive generality of legal regulations concerning the role of organizations in the sphere of supervision over the animal protection system, and lack of regulation of the forms of cooperation of social organizations with administrative authorities, veterinary service and veterinary self-government. The above remarks on the administrative and legal instruments of animal protection used by social organizations in the system of protection do not, in my opinion, give grounds to formulate a categorical thesis about the low impact of these organizations on the effectiveness of the system. They simply act where the administrative apparatus fails.

The most important aspects of the organization's activity - apart from its consultative and educational functions - are establishing and running shelters and the right to intervene in cases of mistreated animals, including the right to temporarily remove them from former owner or guardian. Despite the controversy surrounding the constitutionality of the latter power, it cannot be denied that these activities provide real help to suffering animals. In any case, the constitutionality of this regulation is defensible - it is applied only in emergency situations, when the life and health of an animal are at risk, the taking away of an animal is temporary, not definitive, and it is "sanctioned" by a decision of a public administration body in a form characteristic for administrative law.

While the solution to the problem of the right of organizations to sue in cases of temporary removal of an animal from its previous owner or guardian should be welcomed, the proposal to allow social organizations to initiate proceedings or to participate as a party in any pending administrative or court proceedings if there is a need to protect animals should be viewed with caution. The current regulation of Article $31 \mathrm{CAP}$, authorizing organizations to initiate proceedings and to join proceedings as parties, is optimal for securing the rights of animals. Extending

\footnotetext{
${ }^{25}$ See E. Kruk, Opinia ..., p. 4.
} 
the organization's authority in this regard may have the side effect of significantly prolonging and even paralyzing administrative and judicial proceedings.

In today's reality, in order to ensure the effectiveness of cooperation between organizations and administrative bodies and other entities, the legislator should define a basic catalog of forms of this cooperation, including in particular the powers of social organizations on the supervisory level in matters concerning animal protection. Leaving the cooperative provisions as they are is baseless "as an anachronism leading to dilution of responsibility for the fate of animals" ${ }^{26}$ Meanwhile, social organizations could significantly support the Veterinary Inspection, which is struggling with staffing problems and an overload of duties related to food safety and infectious animal diseases (ASF, bird flu). The latest amendment to the Animal Protection Act passed by the Parliament does not give a chance to achieve this goal, as it is limited to allowing social organizations to have an insight into all supervisory activities over entities running shelters. Such an ill-considered regulation only reinforces the conviction that the legislator does not really care about the real impact of social organizations on the effectiveness of the system of animal protection supervision. Firstly, this right has been granted to organizations for a long time - on the basis of the Act on Access to Public Information. Secondly, the lack of reference to the appropriate application of the provisions of this Act may lead to unauthorized disclosure of personal data and statutorily protected secrets.

This paper is a contribution to a broader discussion on the directions of socialization and making the system of administrative animal protection more effective. The deficiencies of the administrative law system cannot be justified indefinitely by tightening criminal sanctions in cases of crimes and offenses against animals. The system should be effective enough to prevent the use of criminal sanctions, which should be used as a last resort when all other available measures have failed.

\section{REFERENCES}

\section{Literature}

Biernat T., On the Lawmaking Policy, Discretion and Importance of the Rule of Law Standards, "Studia Iuridica Lublinensia" 2020, vol. 29(3), DOI: https://doi.org/10.17951/sil.2020.29.3.67-85.

Dziedziak W., Wplyw sankcji prawnych i moralnych na skuteczność prawa, "Studia Iuridica Lublinensia" 2015, vol. 24(1), DOI: https://doi.org/10.17951/sil.2015.24.1.67.

Jabłońska-Bonca J., Przesłanki stanowienia norm bez sankcji, "Ruch Prawniczy, Ekonomiczny i Socjologiczny" 1984, vol. 46(4).

${ }^{26}$ Idem, Wspótdziałanie organizacji społecznych z właściwymi instytucjami państwowymi i samorządowymi w ujawnianiu oraz ściganiu przestępstw $i$ wykroczeń określonych w ustawie o ochronie zwierzat, "Studia Prawnoustrojowe" 2019, no. 43, p. 208. 
Janiak P., Czasowe odebranie zwierzęcia $w$ trybie administracyjnym - podstawowe zagadnienia, "Casus" 2019, no. 1.

Kruk E., Opinia nt. uwarunkowań prawnych działań organizacji społecznych na rzecz ochrony zwierzat z dnia 22 stycznia $2021 \mathrm{r}$. (unpublished, prepared as part of the implementation of the research project entitled "The Administrative Law Model of Animal Protection" funded by the National Science Center, UMO-2016/23/D/HS5/01820).

Kruk E., Polish and Estonian Regulations on Homeless (Stray) Animals, "Studia Iuridica Lublinensia" 2021, vol. 30(1), DOI: https://doi.org/10.17951/sil.2021.30.1.145-166.

Kruk E., Współdziałanie organizacji społecznych z właściwymi instytucjami państwowymi i samorzadowymi w ujawnianiu oraz ściganiu przestępstw $i$ wykroczeń określonych w ustawie o ochronie zwierząt, "Studia Prawnoustrojowe" 2019, no. 43, DOI: https://doi.org/10.31648/sp.4621.

Kuszlewicz K., Prawa zwierzat. Praktyczny przewodnik, Warszawa 2019.

Ostojski P., Organizacja spoleczna jako strona postępowania w sprawie odebrania zwierzęcia na podstawie Artykułu 7 ust. 3 ustawy o ochronie zwierząt, "Przegląd Prawa i Administracji” 2019, vol. 116, DOI: https://doi.org/10.19195/0137-1134.116.5.

Ostrowska A., Location of Animal Shelters in the Local Spatial Development Plan in Poland, [in:] Legal Protection of Animals, eds. E. Kruk, G. Lubeńczuk, H. Spasowska-Czarny, Lublin 2020.

Radecki W., Ustawa o ochronie zwierząt. Komentarz, Warszawa 2015.

Smaga Ł., Ochrona humanitarna zwierząt, Białystok 2010.

Stelmasiak J., Administracyjnoprawne aspekty ochrony zwierząt, [in:] Prawna ochrona zwierzat, ed. M. Mozgawa, Lublin 2002.

Szewczyk E., Szewczyk M., Status organizacji spotecznej w postępowaniu prowadzacym do wydania decyzji na podstawie art. 7 ust. 3 in fine ustawy z dnia 21 sierpnia 1997 r. o ochronie zwierząt. Glosa do uchwaty Naczelnego Sadu Administracyjnego z dnia 24 lutego 2020 r., II OPS 2/19, "Orzecznictwo Sądów Polskich" 2020, no. 9.

Wlaźlak K., Funkcja planowania gminy na przykładzie programu opieki nad zwierzętami bezdomnymi oraz zapobiegania bezdomności zwierząt, "Przegląd Prawa Publicznego" 2015, no. 4.

\section{Online sources}

Fundacja Czarna Owca Pana Kota, Filantropi czy złodzieje? O czasowym odbieraniu zwierzat. Raport z monitoringu, Kraków-Wrocław 2019, https://czarnaowca.org/wp-content/uploads/ Czarna-Owca-Filantropi-Czy-Zlodzieje.pdf [access: 9.02.2021].

Opinia Departamentu Prawnego Ministerstwa Ochrony Środowiska z 26 marca 2013 r.w sprawie postępowania ze zwierzętami łownymi w szczególnych przypadkach (DP-024-10/6037/12AVB), http://bip.jaktorow.pl/upload/dp-024-10_6037_12avb_opinia_dep_prawnego_-_zwierzyna-1. pdf [access: 20.02.2021].

Opinia Krajowej Izby Lekarsko-Weterynaryjnej dotyczaca poselskiego projektu ustawy o zmianie ustawy o ochronie zwierzat oraz ustawy o utrzymaniu czystości i porzadku w gminach (druk $n r$ 4257), Warszawa 2011, http://orka.sejm.gov.pl/Druki6ka.nsf/0/F005D64B6021E765C12578BE002965C6/\$file/4257-001.pdf [access: 9.02.2021].

Rudy M., Z kolejna nowelizacja prawa ochrony zwierzat mam same problemy, „Rzeczpospolita”, 26.01.2020, www.rp.pl/Opinie/301269987-Michal-Rudy-Z-kolejna-nowelizacja-prawa-ochronyzwierzat-mam-same-problemy.html [access: 17.02.2021]. 


\section{Legal acts}

Act of 14 June 1960 - Code of Administrative Procedure (Journal of Laws 2020, item 256, as amended). Act of 8 March 1990 on municipal self-government, Journal of Laws 2020, item 713, as amended). Act of 21 August 1997 on the protection of animals (Journal of Laws 2020, item 638, as amended). Act of 24 April 2003 on public benefit activity and volunteerism (Journal of Laws 2020, item 1057).

\section{Case law}

Judgement of the Supreme Administrative Court of 18 July 2015, II OSK 2776/13.

Judgement of the Supreme Administrative Court of 11 January 2018, II OSK 770/16.

Judgement of the Supreme Administrative Court of 11 July 2018, II OSK 1002/18.

Judgement of the Supreme Administrative Court of 30 October 2018, II OSK 2684/16.

Judgement of the Supreme Administrative Court of 3 July 2019, II OSK 1162/18.

Judgement of the Voivodeship Administrative Court in Szczecin of 6 November 2013, II SA/Sz 965/13. Judgement of the Voivodeship Administrative Court in Kraków of 22 December 2014, II SA/Kr $1495 / 14$.

Judgement of the Voivodeship Administrative Court in Wrocław of 3 January 2018, II SA/Wr 711/17. Judgement of the Voivodeship Administrative Court in Kielce of 15 March 2018, II SA/Ke 39/18. Judgement of the Voivodeship Administrative Court in Lublin of 20 June 2018, II SA/Lu 218/18. Resolution of the the Supreme Administrative Court of 24 February 2020, II OPS 2/19, CBOSA.

\section{ABSTRAKT}

Artykuł jest poświęcony zagadnieniu efektywności administracyjnoprawnych instrumentów ochrony zwierząt przyznanych organizacjom społecznym na mocy ustawy o ochronie zwierząt. Celem badawczym opracowania jest analiza administracyjnoprawnych uwarunkowań współdziałania organizacji społecznych z organami administracji publicznej i innymi podmiotami w zakresie ochrony zwierząt i opieki nad zwierzętami, a w rezultacie weryfikacja tezy o niewielkim wpływie działalności organizacji na skuteczność systemu ochrony zwierząt. W ramach realizacji tego celu sformułowano trzy tezy badawcze: 1) brak jest racjonalnych podstaw do odebrania organizacjom społecznym kompetencji do czasowego odbioru zwierzęcia, będącej najskuteczniejszym środkiem ochrony maltretowanych zwierząt; 2) organy administracji publicznej i podległe im służby powinny w szerszym zakresie wykorzystywać potencjał organizacji społecznych w sferze działań konsultacyjno-edukacyjnych; 3) niekorzystny wpływ na skuteczność działań organizacji społecznych w sferze ochrony zwierząt mają fasadowe regulacje dotyczące współdziałania organizacji z organami administracji oraz służbami publicznymi. Artykuł jest opracowaniem o charakterze naukowo-badawczym o krajowym zasięgu badań. W zamiarze autorki stanowi przyczynek do szerszej dyskusji na temat kierunków uspołeczniania sytemu ochrony zwierząt.

Słowa kluczowe: organizacja społeczna; ochrona zwierząt; opieka nad zwierzętami; czasowe odebranie zwierzęcia; działania konsultacyjno-edukacyjne; współdziałanie 